\title{
A Review of Paul Auster Studies*
}

\author{
Long Shi \\ College of Foreign Language \\ Pingdingshan University \\ Pingdingshan, China
}

\author{
Qingwei Zhu \\ College of Foreign Language \\ Pingdingshan University \\ Pingdingshan, China
}

\begin{abstract}
Paul Benjamin Auster is a famous contemporary American writer. His works have won recognition from all over the world. So far, the Critical Community contributes different criticism to his works from varied perspectives in the West and China. This paper tries to make a review of Paul Auster studies, pointing out the achievement which has been made and others need to be made.
\end{abstract}

\section{Keywords-a review; Paul Auster; studies}

\section{INTRODUCTION}

Paul Benjamin Auster (born February 3, 1947) is a talented contemporary American writer with great abundance of voluminous works. By far, he has published eighteen novels, seven collections of poetry, five screenplays, four memoirs, one autobiography, a collection of letters exchanged with J. M. Coetzee, some essays and some translations. He is praised for the multifarious styles and varied perspectives. His books have been translated into more than forty languages.

His extraordinariness earns him international fame and he has been nominated and received numerous awards, including the 1978 Columbia - PEN Translation Center Award, the 1985 nomination for the Edgar Award for City of Glass, the 1989 Prix France Culture De Littérature Étrangere for The New York Trilogy, the 1990 Morton Dauwen Award and the Lire Award from the American Academy and Institute of Arts and Letters, nominated for the PEN/Faulkner Award for The Music of Chance in 1991, the 1992 Prix Medicis for the Best Foreign Novel Published in France, the 1993 Prix Medicis Étranger for Leviathan, the 1996 Bodil Awards - Best American Film and the Independent Spirit Award - Best First Screen Play for Smoke, the 1996 John William Corrington Award for Literary Excellence, and the 2006 Prince of Asturias Award for Literature (received in Previous years by Gunter Grass, Arthur Miller and Mario Vargas Llosa). In 2006, Peter Boxall included six of Auster's novels into the collection 1001 Books You Must Read Before You Die and in 2007, Auster was awarded honorary doctor from the University of Liege, and then he was elected as the Vice - President of PEN American Center. IMPAC Award Longlist for The Brooklyn Follies in 2007, Commandeur de l'Ordre des Arts et des Lettres in 2007, IMPAC Award Longlist for Travels in the Scriptorium in 2008, Premio Leteo (León, Spain) in 2009,

*This Paper is a part of project PXY-BSQD-2018019 and sponsored by Pingdingshan University.
Médaille Grand Vermeil de la Ville de Paris in 2010, IMPAC Award Longlist for Man in the Dark in 2010, IMPAC Award long list for Invisible in 2011, IMPAC Award long list for Sunset Park in 2012, NYC Literary Honors for Fiction in 2012.

\section{A REVIEW OF PAUl AUSTER's LITERARY CREATION}

In 1982, Paul Auster published The Invention of Solitude which reflected a literary mind that was to be reckoned with. It consists of two sections. Portrait of an Invisible Man, the first part, is mainly about his childhood in which there is an absence of fatherly love and care. His memory of his growth is full of lack of fatherly attention: "for the first years of my life he would leave for work early in the morning, before I was awake, and come home long after I had been put to bed. I was my mother's boy." (20). Portrait of an Invisible Man, as a matter of fact, is Auster's quest for father. The Book of Memory, the second part, narrative view point shifts from Auster as son to the role as a father, he contemplates the themes of separation, death, chance, and the solitary nature of storytelling and writing, which will be the subjects in his following novels.

City of Glass came out in 1985, Ghosts and The Locked Room in 1986. In 1987, Auster published The New York Trilogy which consists of the three fictions mentioned above, which earned Auster a label of postmodernism writer, Auster became an overnight sensation. From then on, Auster comes to gain more appreciation and produce more works. Since 1987, Auster published nineteen novels: The New York Trilogy (1987), City of Glass (1985), Ghosts (1986), The Locked Room (1986), In the Country of Last Things (1987), Moon Palace (1989), The Music of Chance (1990), Auggie Wren's Christmas Story (1990), Leviathan (1992), Mr. Vertigo (1994), Timbuktu (1999), The Book of Illusions (2002), Oracle Night (2003), The Brooklyn Follies (2005), Travels in the Scriptorium (2006), Man in the Dark (2008), Invisible (2009), Sunset Park (2010),4321(2017); one autobiography: The Invention of Solitude (1982); A collection of letters exchanged with J. M. Coetzee: Here and Now: Letters, 2008-2011 (2013); four memoirs: The Art of Hunger (1992), The Red Notebook (1995), Hand to Mouth (1997), Winter Journal (2012); five screen plays: The Music of Chance (film) (1993), Smoke (1995), Blue in the Face (1995), Lulu on the Bridge (1998), The Inner Life of Martin Frost (2007); seven collections of poems: Unearth(1974), Wall Writing (1976), Fragments from the Cold (1977), Facing the Music (1980), Disappearances: Selected Poems 
(1988), Ground Work: Selected Poems and Essays 19701979 (1991), Collected Poems (2007); and some critical essays and translations.

\section{THE RECEPTION OF PAUL AUSTER'S FiCTIONS IN THE CRITICAL COMMUNITY}

\section{A. Praise on Auster's Works in the West}

The publishing of Auster's novels has been received by mostly positive reviews in the West, especially in France and other parts of Europe. To say the least, his reputation in France helps him to gain wider acceptance in American academia. J. Jensen (Magill Book Reviews, 1998) says that in Hand to Mouth: A Chronicle of Early Failure, Auster's slim memoir traces the rough terrain of his first twenty years along that road. Auster devotes not one word to these achievements, concentrating instead on the desperately lean years of his apprenticeship. Auster's knack for languages, as it turned out, enabled him to keep his head above water during the voyage ahead.

Praise from around the World for The New York Trilogy since its publication in 1987. The Village Voice (USA) considers that "By turning the mystery novel inside out, Auster may have initiated a whole new round of storytelling." The Sunday Times (England) comments that "In his vivid modern New York the energies of literary creation are brought vitally alive, in a great American tradition." The Glasgow Herald (Scotland) says that "A stunning, hypnotic book... Auster's virtuosic storytelling achieves a tone at once passionate and detached, and the result is as curious as it is convincing." L'Express (France) praises the book as "one of the great revelations of American literature in recent years... Auster has talent to burn." El Correo Gallego (Spain) thinks that "Paul Auster is a writer of rare intensity." Elstra Bladet (Denmark) evaluates that "A breathtakingly intense and nerve-wracking book, a game of life and death... This is strong stuff — hold onto your seats." De Groene Amsterdammer (Holland) considers that "Paul Auster's taut and remarkable prose works have enriched the American literary tradition." Corriere della Sera (Italy) thinks that "Auster is one of the most inventive writers of his generation." Jan Kjaerstad (Norway) reviews that "Paul Auster has written a sublime and clear-as-glass book, a book of almost frightening transparency and openness, a crystal that refracts light into colors that have rarely been seen before."

When Moon Palace came out in 1989, there are many accolades for it. The New York Times Book Review comments as "Good-hearted and hopeful, verbally exuberant." "Paul Auster's characters are drawn with great generosity and love... in Moon Palace, he finds a new and fascinating voice." by U.S.A.Today. Michiko Kakutani illustrates it in The New York Times as "Reads like a composite of works by Fielding, Dickens, and Twain... Auster has a lot of fun concocting Marco's adventures almost as much fun as one has in reading them." The Cleveland Plain Dealer says it is a big-spirited romance. Booklist considers that "This wry and magnetic novel glows with lunar images, and, like the moon, fascinates". Newsday says that "Moon Palace offers the gift of self-assured, gracefully flowing prose". Chicago Tribune suggests that "For those who love the gamesmanship of reading... Auster's fiction is a delight...Especially successful is his moon motif, central to his themes of presence and absence, parent and child". Providence Sunday Journal reviews that "Moon Palace offers us a wonderful intellectual exploration - sometimes playful, sometimes serious". The San Diego Tribune comments that "Moon Palace is an oasis in the lunar landscape of modern fiction". Fort Worth Star-Telegram evaluates that "One of the best books I've read ... From first paragraph to last Moon Palace is absolutely superb. If there's literary justice, Thomas Effing will become as familiar to American readers as Huck Finn, Scarlett O'Hara, and Captain Augustus McCrae". The New Criterion comments that "Lean, fluid, vigorous, and delightfully lucid...an intellectually engaging meditation on self and other, solitude and society, mind and matter - and on art as 'a method of understanding, a way of penetrating the world and finding one's place in it'... a testament to Auster's imaginative powers... strange and arresting".

When Leviathan came out in 1992, Auster and the novel receive rave reviews. The New York Times Magazine says “Auster's most accessible, engaging book. He treats us to his best clear-eyed prose." Los Angeles Times considers "Brisk and compelling... Auster's powerful narrative engine keeps us reading and rushing toward a breathless conclusion." New York Newsday evaluates "Paul Auster's novels are beautiful designed artifacts, intellectual puzzles dedicated to the proposition that life is a mystery ruled by chaos and chance. In counterpoint to their message, they are propelled by the most fluid and graceful of prose styles." The Washington Post Book World responds as "Unnerving... Contains occasional patches of gorgeous prose, but more often the style is deliberately spare, a stainless steel string for all the gaudy narrative prose." San Francisco Chronicle comments "Auster's sleight of hand imbues his work with a haunting sense of the uncanny." Chicago Sun-Times thinks "Contains bounties of intelligence, mystery and literary magic sufficient to nourish and delight the mind." Chicago Tribune holds that "The allure of Auster elegant plotting, the play of his ideas, and the sensuous pleasure of his prose keep us firmly hooked." Harper's Bazaar considers "A master of modern novel... Auster combines good old-fashioned mystery narratives with intensely literary forms." St. Peterburg Times says "Compelling, exhilarating... Literary art can work some powerful magic after all.” Library Journal thinks "Suspenseful and meditative... blends a crime story with a thoughtful examination of important psychological and moral questions."

When Mr. Vertigo was published in 1994, most of the comments are very insightful. Los Angeles Times summarizes "Mr. Vertigo is a thrilling flight of fancy that never abandons the world. A magical pertinent book, it gives us a bird's-eye view of the strange, violent, paradoxical century behind us." People say, "A rollicking tale of greed and redemption... Auster has created a character that will remain aloft in readers". Harper's Bazaar evaluates that "An exuberant novel of ideas...strange and masterful... Walt 
Rawley may well be Auster's finest creation...his is a shrewd, larger-than-life American voice in the tradition of Huck Finn and Holden Caufield." Details comments, "Mr. Vertigo proves that nothing beats a good old yarn." Entertainment Weekly evaluates that "The language crackles, the plot jumps, and the characters astonish in this tale of magic and loss, loneliness and exaltation." The Boston Phoenix considers that "Auster soars on the wings of a metaphor with a tale that's light and engaging — as well as fraught with menaning". Playboy comments as "Auster Americanizes a miracle and takes us to a place where only magicians have gone before." Chicago Tribune thinks that "Beautiful writing does soar, and his best, Auster makes it look easy."

Timbuktu has been well received by Critics. James Gardner evaluates in National Review in 1999 that Auster handles the language better than almost anyone else writing today, and that at least the first chapter of Timbuktu, the telling of a human story through the eyes of a pet, is one of the finest and most polished to have appeared in any recent novels. He also says that surely Auster has won a respectable amount of praise in this country. But that is nothing compared with the renown he enjoys abroad. From Amsterdam and Paris all the way to Buenos Aires and Rio de Janeiro we see young people toting paperback copies of his New York Trilogy. In France especially, where he has lived and been a translator, he has acquired that special status reserved only for the likes of Jerry Lewis, Mickey Rourke, and Edgar Allen Poe. Daniel R. Bronson thinks in World Literature Today (Spring 2000, Vol. 74 Issue 2) that Paul Auster's slender novel Timbuktu is a minstrel show in dogface. Mr. Bones, the central figure, is an idealized dog, an ideal companion, and perhaps the consummate silent observer of humanity at its best, worst, and looniest - all qualities exemplified by his master, Willy G. Christmas. This brief, simple tale may be Paul Auster's most accessible novel, intellectually and emotionally. What keeps it from being simply Auster-lite is the humanity of a dog.

Reviewing Invisible, J. Isela and Pena-Rager think (Library Journal, 3/1/2010, Vol. 135 Issue 4), that Auster deals with incestuous love, the magnetic power of intelligent evil, injustice, and self-discovery. His use of intertextuality and his crisp, simple prose will keep readers fully engaged from beginning to end. For all appreciators of contemporary literature, "If you've never read Auster, this is a great place to start". Robert L. McLaughlin comments in Review of Contemporary Fiction (Summer 2010, Vol. 30 Issue 2) "like The Book of Illusions (2002), Oracle Night (2003), and Brooklyn Follies (2005), Invisible features a writer trying to bring coherence to his broken world through narration. The result, of course, is not the discovery of the truth, but more doubt". Auster has given us another brimming with questions whose answers lie in the unrecoverable past and the darkness of the human heart.

Reviewing Sunset Park, Sally Bissell says (Library Journal. 7/1/2010, Vol. 135 Issue 12) that the author deftly balances minute details that evoke New York City, postfinancial meltdown, with marvelously drawn characters bruised but unbowed by life's vicissitudes. Auster has an impressive array of literary nominations to his credit (e.g., PEN/Faulkner, IMPAC Dublin, and Edgar), but this, should be the novel that brings him a broader readership. New Yorker considers that Sunset Park is a story more rooted in time and place than most of Auster's existential yarns. Auster's usual motifs - a figure who disappears from his own life, a prominent role for chance and coincidence, an obsession with baseball and old movies - eventually take over the novel, with familiar results. Kirkus Reviews says that Sunset Park is a very different novel for him, rooted in the realities of contemporary America - most specifically an ongoing war in Iraq and an economic recession that threatens employment in general and the publishing business in particular. Frances Coady, Auster's editor, calls this "a passionately lyrical novel exploring America's predicament today as it follows the inner and outer struggles of a cast of unforgettable characters through the dark months following the 2008 economic collapse."

\section{B. Studies Abroad}

The criticism on his works, which began in the 1980s, begins to flood in the following decades in the Western world. Since 1987, Auster has published many works, especially his novels, has been praised for its narrative complexity, skillful use of point of view, razor-sharp prose and philosophical thoughts. In the spring of 1994, Saint Joseph College in Connecticut held an "Auster seminar". In 1995, the Dutch critic Derek Rubin examines the hunger theme and the connection with the Jewish convention, in the same year, Dennis Barone compiled Beyond the Red Notebook, the first book-length study of Paul Auster's fictions. In 1999, Bernd Hercogenrath published An Art of Desire: Reading Paul Auster. In this book, deconstruction theory is employed. In 2001, Aliki Varvogli published The World That Is the Book: Paul Auster's Fiction, which discusses the influence from the "literary fathers" on Auster as well as the recurring themes in his later woks. In 2002, Ilana Shiloh produced Paul Auster and Postmodern Quest: On the Road to Nowhere, which explores the employment of the postmodern philosophy. In 2004, Harold Bloom edited Paul Auster, in which many critics offer different perspectives on his novels and autobiography. In this edition, Harold Bloom makes the introduction; Charles Baxter examines "The Bureau of Missing Persons"; Stephen Freedman explores "Paul Auster and the Consequences of Confinement"; Pascal Bruckner discusses "Paul Auster, or The Heir Intestate"; William Dow studies "The Invention of Solitude: Glimmers in a Reach to Authenticity"; John Zilcosky explores "Paul Auster's Challenge to Theory"; Alison Russell speculates upon "The New York Trilogy: Paul Auster's Anti-Detective Fiction" Steven E. Afford explores "chance" in Auster's narrative; Tim Woods examines "Urban Space and the Postmodern in In the Country of Last Things"; Linda L. Fleck discusses "From Metonymy to Metaphor" in Auster's Leviathan. Michael Dirda opined "Over the past twenty-five years, Paul Auster has established one of the most distinctive niches in contemporary literature." in The New York Review of Books in 2008. After the publication of Travels in the Scriptorium in 2006, and receiving Prince of Asturias Award for 
Literature, Auster has become more and more well-known literary figures in America and in western literature world. In the circle of studies on Auster, another five books should merit our attention best, Understanding Paul Auster by James Peacock, Existentialism and Baseball: The French Philosophical Roots of Paul Auster by Tom Theobald, and The Implosion of Negativity: The Poetry and Early Prose of Paul Auster by Andreas Hau, Paul Auster's Postmodernity by Brendan Martin, and Paul Auster by Mark Brown.

There are some comprehensive studies of Auster's novels. In Timothy Bewes' paper "Against the Ontology of the Present: Paul Auster's Cinematographic Fictions" (Twentieth Century Literature. Fall 2007, Vol. 53 Issue 3), Bewes reads in the light of Lukács's aesthetics of cinema Mr. Vertigo, The Book of Illusion and Oracle Night, Timothy Bewes argues that Auster's fiction seems determined to play out the demise of fiction itself; yet this determination has its contrary structurally embedded in it, because in cinema, the destruction of the work is unnecessary for the affirmation of life, for the simple reason that cinema is not predicated on the notion of presence, of ontology. James Peacock, in "The Father in the Ice: Paul Auster, Character, and Literary Ancestry", writing for Critique (2011, Vol. 52 Issue 3), takes as its starting point the image of the father frozen in ice that Paul Auster first uses in Ghosts. He argues that the image can be read as a representation of Auster's relationship with his literary antecedents and as a dramatization of the ethical questions of solipsism and otherness that the reading of narrative entails. William Marling, in the paper "Paul Auster and the American Romantics" (LIT: Literature Interpretation Theory; 1996, Vol. 7 Issue 4) analyzes how Paul Auster responds to the American romantic writers as his "inheritance." He invokes these writers in his own biographical circumstances to reinstate Auster the "author" in his own web of textuality. This illustrates Mikhail Bakhtin's theory of the "chronotopic" as an exchange between works and readers in a historically developing social world. Auster's reading of Nathaniel Hawthorne features most prominently in The Locked Room, in which the narrator searches for a vanished writer named Fanshawe, the protagonist of Hawthorne's first novel. In the thesis, "In the Country of Missing Persons: Paul Auster's Narratives of Trauma" (Studies in the Novel. Spring 2009, Vol. 41 Issue 1), Debra Shostak examines Auster's six novels (City of Glass, The Brooklyn Follies, In the Country of Last Things, Leviathan, The Book of Illusions, Oracle Night), then points out the narrator's desire to erase an absence aims toward uncovering secrets - and the fact of narration both testifies to and enables the quest. Each quest stands for the narrator's confrontation with trauma.

There are comparatively large numbers of academic papers on Auster's single novel. William Dow, in his paper "Paul Auster's The Invention of Solitude: Glimmers in a Reach to Authenticity" (Critique; Spring 98, Vol. 39 Issue 3), suggests that Paul Auster's The Invention of Solitude employs but also questions the validity of postmodern typologies and can thus properly be read in relation to recent postmodernist theory. At the same time, it challenges the idea that autobiography comes from a preexisting self or a unique and autonomous self. Auster's "autobiography," consequently, constructs a self that requires negotiation, collusion, and complicity as it fashions the material of the past to "serve the needs of the present consciousness." However, Auster also goes against postmodernist theory, expressing his own epistemology and theory of literary expression. The Invention of Solitude challenges the postmodernist topos of demonstrating that the discourse of humanism and rationalism serve only to conceal irreconcilable and in-determinant meanings. It stresses the end of a single worldview, but it simultaneously values the "partial, glimpsed achievements" of the novel's narrators. Dennis Barone's paper "Auster's memory", writing for Review of Contemporary Fiction (Spring 94, Vol. 14), examines memory in Paul Auster's The Invention of Solitude. Auster of solitude centers himself through a historical search, and the center revealed by that search is ever changing. Part one of the Solitude gives us a man apart and invisible in a first-person narration, whereas part two presents us with a person connected to the world through memory in a third-person narrative.

Studies on City of Glass vary from different perspectives. In the thesis, "Nothing to Go on: Paul Auster's City of Glass." (Contemporary Literature. Spring 97, Vol. 38 Issue 1,) William G. Little thinks that Auster's postmodern potboilers are harder to digest because nothing works out in the end, or, rather, nothing works out through the loose ends of the texts forever unfinished fabrics. Auster's refrain of nothing leaves the readers perpetually hungry by pointing toward that which inevitably gets excluded in the logocentric claim to comprehensive understanding of self and the world. William Lavender analyzes City of Glass from the perspective of deconstruction in the thesis "The Novel of Critical Engagement: Paul Auster's City of Glass" (Contemporary Literature. Summer 93, Vol. 34 Issue 2), he argues that City of Glass is a deconstruction or sabotage. It deconstructs the form of the novel, the canons of criticism, theory and tradition, and it deconstructs itself, as it literally falls apart in its progression. It could be argued that Auster's seemingly obsessive engagement of theory reduces the novel to an academic enterprise, robbing the form of social and political relevance. Sylvia Söderlind analyzes in "Humpty Dumpty in New York: Language and Regime Change in Paul Auster's City of Glass." (Modern Fiction Studies. Spring 2011, Vol. 57 Issue 1) the characterization of the philosophical egg, Humpty Dumpty II, and explores the significance of the parable of the Tower of Babel in the narrative. It also looks into the story of the fall of Humpty Dumpty in terms of the development of party politics in the US. Jeffrey T. Nealon explores Paul Auster's novel City of Glass in "Work of the Detective, Work of the Writer: Paul Auster's City of Glass." (Modern Fiction Studies. Spring 96, Vol. 42 Issue 1) in a metaphysical and metafictional genre from the following perspective: objects and relation to language; inadequacy in modernist view; kind of radical neutrality; writer's belongingness to the frozen, fascinated time of image; first person to third person slippage of writing. Marjorie Worthington examines connection of the novel with the book Don Quixote by Miguel de Cervantes Saavedra in “Auster's City of Glass.” (Explicator. Spring 2006, Vol. 64 
Issue 3), closer examination reveals that Auster's reading of Don Quixote is a key to our understanding of City of Glass. In the thesis, "From one mirror to another: the rhetoric of disaffiliation in City of glass" (Review of Contemporary Fiction; Spring 94, Vol. 14), Chris Tysh discusses the issues and textual strategies in Paul Auster's City of Glass. Although this work contains the classical features of a detective novel, she observes, it also shows signs of being a philosophical investigation habitually reserved to metaphysics. She notes that this mixing of genres places Auster's literary works within postmodernism. To the degree that the work participates in deconstructing the heavenly tower of the father's city and his language, she explains, City of Glass chronicles the Babel-like confusion and decay of modernity and, simultaneously, parallels postmodernism's crisis of representation. Pascale-Anne Brault, in the paper "Translating the Impossible Debt: Paul Auster's City of Glass" (Critique; Spring 98, Vol. 39 Issue 3), argues that City of Glass must be read against the background of the pervasive 17th and 18th century rhetoric of America as the new Eden. Set in late-20th-century America, the novel borrows that rhetoric to expose the dangers of fusing the biblical promise to a particular historical location: the risks of exclusion that result when the biblical promise is said to be realized in a chosen people, land, and language. It offers an exemplary space to question the extent to which America offers, or could ever offer, a vision of a multiplicity of languages, of the experience of a Tower of Babel. While it clearly demonstrates the dangers of seeking a single, pure, transparent language, a language of God, the English language of the novel ends up controlling or usurping the place of any language into which one tries to translate it at the very place and moment where translation would appear to be most easily assured.

Alex Segal's thesis "Secrecy and the Gift: Paul Auster's The Locked Room.” (Critique; Spring 98, Vol. 39 Issue 3) argues that the significance of some of the key topics explored by Paul Auster in The Locked Room can only be understood in relation to the problematic of the gift advanced by Jacques Derrida. He finds that thinking of Auster's text in terms of the gift can help us better to understand its metafictional and metanarrative features because at stake in the paradox of the gift is the gift's relationship to narrative. He finds, moreover, that Derrida's account of the gift suggests how Auster's work can be ethically responsive at the same time as it challenges the humanist conception of character and privileging of the category of the subject that arguably informs the "classic realist" text. Perhaps most important, he contends, is that Derrida's work enables us to take account of the way that the ethical as it is thematized by Auster's novel is characterized by that which common sense opposes to ethical responsibility, namely, secrecy.

Eric Berlatsky's "Everything in the World Has Its Own Color: Detecting Race and Identity in Paul Auster's 'Ghosts"', writing for Arizona Quarterly (Autumn 2008, Vol. 64 Issue 3) holds that although a postmodern or poststructuralist understanding of "race" would usually be quick to dissolve the arbitrary binaries of "white" and "black," Auster's work in general, and Ghosts in particular, complicates this model. Auster's self-conscious play with colors and their variable meanings in Ghosts appears initially to function on the same level as his play with words, highlighting their role as slippery signifiers that undercut "essential" constructions of race. Simultaneously, however, racial division remains in the unconsciousness of text, preventing the total dissolution of racial categories for which the novel appears to strive. While Auster works diligently to deconstruct self/other binaries in a theoretical sense, the material actuality of American racial history and its psychological after-effects prove to be intractable to his theoretical revision.

Since the publication of In the Country of Last Things, different perspectives are used to analyze this novel. Maya Merlob, in "Textuality, Self, and World: The Postmodern Narrative in Paul Auster's In the Country of Last Things" (Critique. Fall 2007, Vol. 49 Issue 1) explores the spatialization of textuality that characterizes the postmodern narrative in In the Country of Last Things. The article discusses the debunkment of time as an ordering principle of narrative and the transformation of space into the dominant textual feature. The novel introduces various spaces geographical, subjective, authorial, historical, and literary that has an uneasy relationship and creates the text as an incongruous spatial network. The spaces continually split, deconstruct, and reconstitute themselves, producing a textual site that is incoherent, unstable, and discontinuous. In the thesis, "A Book at the End of the World: Paul Auster's In the Country of Last Things." (Review of Contemporary Fiction; Spring 94, Vol. 14) Katharine Washburn argues that In the Country of Last Things would appear at first glance to be a sharp turn in literary direction. This impression comes from the apparent straightforwardness and almost complete lack of the formal conundrums and cross-referenced allusions for which New York Trilogy is noted. In the Country of Last Things, however, it shows, if anything, greater cunning and obliqueness behind the same screen of lucid and uncompromising prose. Rather than being occupied with a future dystopia, In the Country of Last Things concerns a hellish present, and its characters belong to the ethical, spiritual, and cultural chaos of the here and now. Auster has succeeded in constructing a world of demolished things, which we are forced, immediately and painfully, to recognize as our own. Sven Birkerts discusses the technique and theme in In the Country of Last Things in "Reality, Fiction, and In the Country of Last Things" (Review of Contemporary Fiction; Spring 94, Vol. 14). He thinks that Auster, in exploring the real by means of the invented, reasserts the traditional rights of the genre of self-reflexive fiction. He has not, however, gone back to naturalism - he is too much of a modernist for that — but he does allow us to forget that the story is the product of a superintending author. The resonances between Auster's tale of arrival, entrapment, and terror and other 20th-century works suggest that it may be archetypal. Indeed, it might be seen as the emblem par excellence of the soul's horror at existence.

Among Auster's novels, The New York Trilogy increasingly comes to address topical issues. Steven E. Alford, in the thesis "Mirrors of Madness: Paul Auster's The 
New York Trilogy" (Critique. Fall 95, Vol. 37 Issue 1) examines the identity of the narrator of the stories, which focuses on connection between narrator and characters. Ramon Espejo, in "Coping with the Postmodern: Paul Auster's New York Trilogy." (Journal of American Studies. Feb. 2014, Vol. 48 Issue 1) offers a reconstruction of Auster's dialogue across both and resists situating the novelist in either the modern or the postmodern camp. In "Deconstructing The New York Trilogy: Paul Auster's Anti - Detective Fiction" (Critique. Winter 90, Vol. 32 Issue 2), Alison Russell argues that New York Trilogy is a highly entertaining yet sophisticated work, amenable to the deconstructive principles of Jacques Derrida. All three employ and deconstruct the conventional elements of the detective story, resulting in a recursive linguistic investigation of the nature, function, and meaning of language. Like language itself, the three texts are incessant play of "différance", meaning is deferred in an endless movement from one linguistic interpretation to the next. Auster reinforces this deconstructive effect through the use of other language games, such as intertextual references, mirror images, and puns, thereby exploding the centering and unifying conventions of detective stories. Roberta Rubenstein, in "Doubling, Intertextuality, and the Postmodern Uncanny: Paul Auster's New York Trilogy (LIT: Literature Interpretation Theory. Dec 98, Vol. 9 Issue 3) examines the construction of the uncanny in The New York Trilogy, Auster's intertextual play with doubles, names and identities. Scott A. Dimovitz argues, in "Public Personae and the Private I: De-Compositional Ontology in The New York Trilogy (Modern Fiction Studies. Fall 2006, Vol. 52 Issue 3) that Auster's writings present the disputes and concerns of postmodern theories not in a want to corroborate those theories, but an effort to produce a creative space externally of those theories' logical conclusions. Moreover, he suggests that the book exploits the already used up antidetective genre to explore sides of ontology. In "Spaced-Out: Signification and Space in Paul Auster's The New York Trilogy" (Contemporary Literature; Winter 95, Vol. 36), Steven E Alford comments that one encounters genuinely puzzling characters and spaces. Characters disappear from the space of the novel, seek to lose themselves by wandering through unfamiliar space, use space as an arena for hermetic communication, and design utopian spaces based on their fears and misapprehensions. By looking at how three spaces - pedestrian spaces, mapped spaces, and utopian spaces function in the novels, one can see that thematically a relationship is forged between selfhood, space, and signification. The problem experienced by all the protagonists in the Trilogy is a lack of understanding that space and the self are coeval, engendered from the possibility for signification that arises from a place that is neither here nor there. In the M.A. thesis "Identity Wars: Postmodern Versus Modern in Paul Auster's The New York Trilogy", Teresa Keoppel from California State University argued that traditionally the study of identity has been the search for a discoverable, stable set of characteristics that fix one's sense of self within an unchanging meaning-matrix. Philosophical thought systems were dependent on the belief that the language used to describe and explain the world was a divine gift of God. As such, language had a fixed meaning grounded in the concept of the transcendent signified: God gave the word (language); the word was good (meaningful); therefore the word corresponded to the object (world). With the evolution of poststructural theory, language began to be seen not as the divine gift of God with a fixed meaning, but as a constructed tool of man whose meaning was constantly in flux. This study seeks to explain and delineate the differences between a modernist and postmodernist view of language. In Joan Alcus Dupre's Ph.D. dissertation of City University of New York "Fighting Fathers/Saving Sons: The Struggle for Life and Art in Paul Auster's New York Trilogy, the study offers a new reading of the three novels. His claim is that in order to fully appreciate Auster's fiction, it is essential that we understand how the relationship between fathers and sons functions for Auster on three levels. The first level is biological paternity. We must be aware of the significance of Auster's troubled relationship with his biological father, for this uneasy bond underlies and is manifested in all of Auster's work. The second level is literary paternity, which involves Auster's relationship with his literary forefathers, especially Cervantes, Thoreau, Hawthorne, and Poe. These literary fathers are the ghosts that haunt the Trilogy — the positive father figures Auster wrestles with and ultimately embraces. The third level is ethical and aesthetic paternity, the level on which Auster's progeny, his characters, operate. These are the father and son figures who are also detectives and writers who embark on quests to save or at least fathom - a son or a father. These characters and their quests reflect Auster's struggle with his biological and literary fathers and his ethical and aesthetic agenda. The dissertation explores the themes of loss and solitude and the confusion we may feel in this postmodern age when the lines between reality and illusion are hopelessly obscured, the belief in the value of art is tenuous, and the battle to live as a solitary writer without severing human contact and destroying oneself can be torturous. Finally, however, the Trilogy validates the heroism of its protagonists and ends with the very bridging of chasms that seems impossible at the beginning of the first novel. Therefore, this study underscores what the author submits is foregrounded in the novels: the human relationships and the art that endures.

By analyzing Fogg, Moon Palace's traumatized protagonist, Debra Shostak in "Under the Sign of Moon Palace: Paul Auster and the Body in the Text." (Critique. Winter 2008, Vol. 49 Issue 2) proposes that Paul Auster addresses the epistemological contradiction between a poststructuralist reality as constructed by the subject through language and an acknowledgment of materiality and the real of referential history. As Auster deconstructs such oppositions as subject/object and "I"/body, the novel posits the conditions under which a representational mode of realism may coexist with the postmodern. In Moon Palace, Auster would seem to butt postmodern theory up against the hard reality of physical existence, not to produce synthesis but rather to see what contradictions rise to the surface. Kanae Uchiyama focuses on the physical dimensions of hunger, nausea, sleep, sexuality, aging and death. Accordingly, the author discusses the difference between the 
desire to eat and the desire for representation in the exchanges between philosophers Emmanuel Levinas and Martin Heidegger in "The Death of the Other: A Levinasian Reading of Paul Auster's Moon Palace" (Modern Fiction Studies. Spring 2008, Vol. 54 Issue 1) In "Inside Moon Palace." (Review of Contemporary Fiction. Spring 94, Vol. 14), Steven Weisenburger argues that Paul Auster's Moon Palace is preoccupied with the problem of the inside. The novel's action unfolds through a series of quests for natural language, fathers, authority, and history, always occurring within claustrophobic interiors. These spaces are sites for a degenerative obsession for origins and power that is dimly backlighted by oblique references to the historical 1960s. The characters' loss of a continuous and coherent genealogy is plotted as the occasion for these degenerative obsessions. Literally and ideologically central to the novel is the discussion of the canvas moonlight by obscure 19th-century American landscape painter Ralph Albert Blakelock whose place in the genealogy of American art is hardly acknowledged.

Warren Oberman, in "Existentialism Meets Postmodernism in Paul Auster's The Music of Chance" (Critique. Winter 2004, Vol. 45 Issue 2), supposes that in trying to reinvent the existential self to fit contemporary consciousness, the postmodern writer faces a double task: the work must respond both to the mainstream of postmodern thought and to the beleaguered and oft-challenged humanist tradition. This creates a duality that few writers have manipulated as deftly as Auster has in The Music of Chance. In The Music of Chance, Auster's uncanny ability to inform postmodern thought with theme is remarkable. In "A Place Both Imaginary and Realistic: Paul Auster's The Music of Chance" (Contemporary Literature. Fall 2002, Vol. 43 Issue 3), Iana Shiloh draw the conclusion that The Music of Chance begins as a classic American road and imperceptibly shifts into the mold of a Greek tragedy. These two incompatible modes are thematically interlaced by the motif of chance and determinism, fatherhood, freedom, and money, which are constructed and deconstructed in the context of individual life and that of the national American ethos. In his thesis "The Currents of Fate and The Music of Chance" (Review of Contemporary Fiction. Spring 94, Vol. 14), Paul Bray examines the nature of fate and circumstance in Paul Auster's The Music of Chance. Bray argues that this novel is shaped in ways that subvert almost every expectation a reader could have with regard to conflict, rising action, resolution, and so forth. With The Music of Chance, Auster has invented a wholly new kind of fiction. In "The Game of Late Capitalism: Gambling and Ideology in The Music of Chance" (Mosaic: A Journal for the Interdisciplinary Study of Literature; March 2000, Vol. 33 Issue 1), Eyal Dotan explores the novel alongside the theories of Jean Baudrillard. The relevance of Baudrillard, she explains, is his concept of capital and late capitalism in general, as modeled on games of chance. They find that Baudrillard's concept chimes with Auster's novel in a way that suggests a possible analysis of the symptomatic phenomenon of gambling. That analysis also suggests a link (however hostile) between Baudrillard's account of late capitalism and contemporary Marxist thought.
Scott A. Dimovitz, in the thesis "Portraits in Absentia: Repetition Compulsion and the Postmodern Uncanny in Paul Auster's Leviathan" (Studies in the Novel. Winter 2009, Vol. 40 Issue 4), argues that Paul Auster's Leviathan provides an excellent forum within which to consider such notions of subjectivity and agency, especially under circumstances where the individual is at odds with cultural and political hegemony, inviting us to question what modes of agency are available for marginalized figures and what the consequences might be for his or her ongoing process of identity construction. In "Phantoms of Liberty: The Secret Lives of Leviathan" (Review of Contemporary Fiction; Spring 94, Vol. 14), Mark Osteen examines the theme of multiple selves in Paul Auster's Leviathan. In this novel, Auster and his alter ego, Peter Aaron, investigate the multiple selves of Benjamin Sachs. The tangled connections among the characters grow from the secrets they share, which generate second selves, "artificial men," phantoms who embody the liberty those covenants both permit and prevent. The novel reaffirms Auster's idea of the multitude unified in every human identity. Furthermore, it suggests that the liberty of absolute solitude is a phantom and that true liberty emerges only through the covenants and bonds of social life.

Jim Peacock examines The Book of Illusions in thesis "Carrying the Burden of Representation: Paul Auster's The Book of Illusions" (Journal of American Studies. Apr. 2006, Vol. 40 Issue 1) and his obsessions into a densely layered system of signification. It argues that many of Auster's novels and their extended anecdotes can be read as versions of the contemporary parable. Auster's texts employ polyphony and deny a nucleus of meaning by consistently framing and reframing characters and events until a sense of objective reality is obscured. Other Puritan influences in Auster are his attention to issues of guilt, salvation and resurrection.

Richard F. Patteson, in the thesis "The Teller's Tale: Text and Paratext in Paul Auster's Oracle Night" (Critique. Winter 2008, Vol. 49 Issue 2), thinks that Oracle Night is filled with writers telling their own stories and the stories of others, but it is also characterized by a concentration on the interface between life and death and on the fragility of human identity. Auster often employs the paratext - an alternate narrative standing apart from the main one yet parallel to it in important ways - to display the role of narrative in the construction and reconstruction of a human reality that constantly hovers on the edge of oblivion.

In the thesis "Paul Auster's Travels in the Scriptorium as a Critique of the Hyperreal" (Explicator. Jan. 2014, Vol. 72 Issue 1) V. Neethi Alexander and Srirupa Chatterjee illustrate that Auster's Travels in the Scriptorium systematically breaks down, among others, the word, the narrative, and the visual image as stable referential to reality. The novel depicts Mr. Blank as a subject under the clutches of hyperreality and concludes with the declaration that a perpetual deferral of reality constitutes postmodern existence. The essay, "The Poetics and Politics of Metafiction: Reading Paul Auster's Travels in the Scriptorium" (English Studies. Apr. 2008, Vol. 89 Issue 2) by Martin Butler and Jens Martin 
Gurr, attempts to shed light on the poetics and politics of metafiction by both sketching the different metafictional devices in the novel and by hypothesizing about their sociopolitical and cultural potential. Auster's attempt at pushing metafictional aesthetics to the extreme is far more than merely a belated me-too afterthought to the metatextual vogue of postmodern art. On the contrary, Martin Butler and Jens Martin Gurr argue that the self-referential mode of the novel highlights the poetic potential of literature as a "room of its own", as a site of both poetological reflection and ideological intervention in extra textual discourses.

In the thesis "Author, Father, President: Paul Auster's Figures of Invisibility" (Canadian Review of American Studies. 2013, Vol. 43 Issue 3), Galia Benziman argues that Auster's representation of current US politics in Man in the Dark emerges from, and becomes intricately entangled with, the already familiar psychological and poetic motifs of his early work - The Invention of Solitude. The confrontation with the father's absence and with the wound it has inflicted occurs through writing, while the narrator struggles to achieve two impossibilities: to resurrect the dead and portray the invisible. Benziman thinks that Man in the Dark is a post9/11 work in which factual and fictional plot lines evolve around current events such as the attack on the World Trade Center, the 2004 presidential election, George W. Bush's controversial leadership, and the Iraq War - a war that casts its awful shadow on the lives of Auster's main characters.

In her article "Echoes of Sophocles's Antigone in Auster's Invisible" (Comparative Literature \& Culture: A WWWeb Journal; March 2011, Vol. 13 Issue 1), Kathleen Waller discusses Paul Auster's Invisible, Waller explores Deleuze's and Guattari's ontological idea of becoming in a virtual world versus merely living in the actual, physical world. The novel is in essence a retelling of Antigone, which exposes the desires for immortality and incest as a connection to a preservation of the family or its uniqueness.

There are also numerous comparative studies between Auster and other writers. In "Paul Auster and Charles Reznikoff: The Hunger-Artists of Jewish America" (An Interdisciplinary Journal of Jewish Studies. Fall 2014, Vol. 33 Issue 1), Izabela Zieba suggests that despite the difference between the two writers, they have common ground: they follow the steps of Kafka and his hunger-artist. Heidi Elisabeth Bollinger, in "The Danger of Rereading: Disastrous Endings in Paul Auster's The Brooklyn Follies and Jhumpa Lahiri's Unaccustomed Earth" (Studies in the Novel. Winter 2014, Vol. 46 Issue 4) argues that like the traditional deus ex machina, or "god from the machine," a device originally employed in Greek drama, resolves a seemingly inextricable narrative bind through a miraculous intervention: lowering a god onto the stage by machine." the invocation of disaster in Auster's and Lahiri's fiction may strike readers as an artificial note because it radically disrupts the internal logic of the textual world - and yet this jarring and artificial effect is perversely fitting because disasters explode the logic of our world. Disaster breaks paradigms: it is the unimaginable appearing on the stage before us. Jutta Ittner, in "Puzzle: Anthropomorphism in Woolf's Flush and Auster's Timbuktu (Mosaic: A Journal for the
Interdisciplinary Study of Literature. Dec 2006, Vol. 39 Issue 4), contrasts the use of anthropology and Paul Auster's Timbuktu. The essay argues that recent animal literature marks a shift from views of animals as connected solely to human consciousness and without its own agency and a newer tradition that characterizes the animal as other and serves to reflect back our own humanity. Newer writings take this question and use it to reconsider the debates surrounding animals' otherness. J.M. Tyree, in "Fanshawe's Ghost" (New England Review; Summer 2003, Vol. 24 Issue 3 ), investigates the repetition of an unusual name, Fanshawe or Fanshaw, in three American novels separated widely in time and literary sensibility. He finds that certain thematic similarities also emerge in the three novels and that the third book invokes the name as a deliberate echo of the first. The three books he considers are Nathaniel Hawthorne's Fanshawe (1828), Patricia Highsmith's The Talented Mr. Ripley (1955), and Paul Auster's The Locked Room (1986). Mark Ford argues that, in "Inventions of solitude: Thoreau and Auster" (Journal of American Studies; August 1999, Vol 33 Issue 2), Henry David Thoreau and Paul Auster are both concerned with the powers of solitude to convert the socially induced anxieties of self-division into the creative forces of self-awareness. In their works, solitude is often presented as enabling a dream-like schism of the self that allows one to follow two paths at once. In the chapter on solitude in Walden, Thoreau notes that when alone he is "sensible of a certain doubleness by which I can stand as remote from myself as from another." This principle also informs "The Book of Memory" in Auster's The Invention of Solitude. Solitude, rather than offering a stable grounding of experience in a single autobiographical discourse, is constructed by both writers as a means of connecting with the world through multiple selves. In M. A. thesis "Authorial Turns: Sophie Calle, Paul Auster and the Quest for Identity" of Carleton University (Canada), Anna Khimasia examines the intertextuality of Double Game and Leviathan, concentrating on Auster's and Calle's self-conscious play with their roles of and as "author" and "subject" continually reinventing and repositioning their identity in relation to their fictional narratives. Khimasia intends to expose how Calle's and Auster's authorial games disrupt the stability and fixity of identity by exploring the possibilities of a shifting plasticity that is always already "under-erasure." She concludes that both Calle and Auster displace and complicate the singularity of the relationship between author/text, author/subject and fiction/truth. Thus, meaning is not produced through a static closure of the binary but through free-play of the signifier. In the M.A. thesis, "American Whiteness and Literary Form in the Aftermath of 1960s Ethnic Nationalism: Paul Auster, Russell Banks, Raymond Carver, and Jane Lazarre", Simon C. Abramowitsch from Howard University uses fiction by Paul Auster, Russell Banks, Raymond Carver, and Jane Lazarre, he argues that the literature of white American fiction writers in the aftermath of the ethnic nationalist period bears the marks of a shift in the American cultural and racial environment that occurred as a result of nationalist movements by activists and artists of color. Kent Chapin Ross from Texas A\&M University in her Ph.D. dissertation 
"Developing a method of literary psychogeography in postmodern fictions of detection: Paul Auster's The New York Trilogy and Martin Amis's London Fields" develops a theoretical method of psychogeographical literary criticism and attempts to test it on the specific genre of postmodern fictions of detection, and on a pair of specific texts of that genre, The New York Trilogy and London Fields. The study employs postmodern theories of literature, knowledge, and ontology from thinkers such as Guy Debord, Michel de Certeau, Jacques Derrida, Julia Kristeva, Mieke Bal, Seymour Chatman, David Herman, and Brian McHale, among others to unearths a number of important narratological points. First, the organic human viewpoint, including the massive power of the human brain, can no longer be neglected in understanding literature. The power of the human observer in space elucidates the multiple and bundled nature of the fictional point of view, the importance of the body as part of setting, the facile ability of the mind to switch between character viewpoints and heterocosms, and the constructed, disseminated, fragmented, and simulated nature of human observation of space. Postmodern fictions of detection as a genre are discovered to be reliant on their troping of traditional epistemological stories of detection with ontological moves that transgress zones. The New York Trilogy contains an incipient psychogeographical agenda in its consideration of the physical and natural world beyond its program of linguistic deconstruction, leading to an "ontological deconstruction." London Fields is also grounded in a psychogeographical mode, built around an understanding of the corporeal nature of human experience of reality as marked with innocence and experience, and the body as a pre-apocalyptic corpse. The conclusion considers the post-postmodern mood as defined by a psychogeographical Weltanschauung, an omniontological world of worlds. In Ph.D. dissertation "In Any Event": Chance, Choice, and Change in the Postmodern Fictional Text" of University of Ottawa, Ryan Maydan attempts to stage a creative encounter between a Deleuzian theory of the event and postmodern fictional narratives. More specifically, it situates subjectivities represented in postmodern texts in relation with concepts of chance, choice, and change in the works by Don DeLillo, Paul Auster, Edmund White, and Nicholson. she draw the conclusion that chance and choice themselves need to be rigorously theorized in order that we better understand the mechanisms of containment and resistance, but most importantly the conditions for emancipatory change within the postmodernism of a new millennium. Kelly C. Connelly in her Ph.D. dissertation "From Poe to Auster: Literary Experimentation in the Detective Story Genre" argues that two dominating lines of criticism regarding the detective novel have perpetuated the misconception that detective fiction before the 1960s was a static and monolithic form unworthy of critical study. First, critics of the traditional detective story have argued that the formulaic nature of the genre is antithetical to innovation and leaves no room for creative exploration. Second, critics of the postmodern detective novel have argued that the first literary experiments with the genre began only with postWorld War II authors such as Umberto Eco, Italo Calvino, and Paul Auster. What both sets of critics fail to acknowledge is that the detective fiction genre always has been the locus of dialectic between formulaic plotting and literary experimentation. She examines how each generation of detective story authors has engaged in literary innovation to refresh and renew what has been mistakenly labeled as a sterile and static popular genre.

\section{Studies in China}

Though Paul Auster has attracted great attention of the critics in the west world after the publication of The Invention of Solitude in 1982, the academic study inside China is rather late and fragmentary. Auster's creation did not begin to attract the Chinese critics' great attention until he received Prince of Asturias Award for Literature in 2006, he was the fourth English writer who received the Award after Doris Lessing, Arthur Miller and Susan Sontag.

In 2002, Auster's works were firstly introduced in the history of American literature in China compiled by Wang Shouren. In 2007, Auster's The New York Trilogy was translated into Chinese by Wen Min. Studies on Auster in China are alongside the translation. So far, there are about seventy-two published papers, twenty-two M.A. thesis, and four Ph.D. dissertations, ("Paul Auster's Quests : Finding One's Place in the Darkness" by Li Qiong of Xiamen University in 2009, "A World Full of Uncertainty — Study on Paul Auster's Novels " by You Nanchun of Beijing Normal Universityin 2010, "A Study of Space in Paul Auster's Novels" by Gao Limin of Shanghai International Studies University in 2011, "Writing Degree Zero, Writing Involvement and Writing between Degree Zero and Involvement" by Li Jinyun of Renmin University Of China in 2011).

Studies on Paul Auster can be classified into different categories in China. There are fruitful theses which focus on the narrative strategy or narrative arts. Hao Yarong, in her thesis "A Study on Paul Auster's Narration", Hao analyzes Auster's narrative strategy, narrative modes and narrative discourse and summarizes Auster's overall narrative forms. In her thesis "The Anti-Detective Narrative Arts in The New York Trilogy", Liu Qijun illustrates how Auster deconstructs traditional detective novel from narrative content, narrative structure and narrative language. In their articles, Cui Dan, Li Jinyun, Jiang Ying, Huang Xia, Zhang Xiaxia, Wu Jingke, narrative strategy or narrative arts of Auster's fictions are analyzed respectively.

Numerous articles and thesis are devoted to the postmodern perspective. Li Wei, in his thesis"A Postmodern Study on The New York Trilogy", explores the postmodernity from the writing of deconstruction and construction, intertextuality, labyrinth and search for subjectivity. In the thesis "The Metafiction in Paul Auster's Novel", Li Weimin discusses the imitation of writer's writing, the process of creation and critics' work in Auster's work, and reveals the novel about novel. In "The Characteristics of Metafiction in Oracle Night", Lian Dawei summarizes three structures of metafiction in the novel, the open structure of metafiction, the imbedded structure and fragmentary structure. Son Ruixue, in her thesis "The Study 
of Uncertainty in The New York Trilogy", explores the uncertainty of identity and uncertainty of language. Song draws a conclusion that Auster deconstructs traditional literary genre with distinct postmodern characteristics. Wang Bo also discusses the uncertainty in his thesis "An Analysis of Uncertainty in The Book of Illusions", in which he attempts to illustrate with the loss of identity, the uncertainty of the signified and chance.

There are two theses on the theme of The New York Trilogy. Fang Fang, in "Breaking of Image, Construction of Self - A Study on the Theme of The New York Trilogy", explores the relation between subject, otherness and language based on Lacan's subjectivity theory. Ren Huan analyzes "The Theme of Alienation in The New York Trilogy" based on Erich Fromm's alienation theory from social space, production and consumption.

Some scholars devote their articles on the language and subjectivity to Auster. $\mathrm{Xu}$ Shibo analyzes the relation between subject and otherness in The New York Trilogy based on Faucault's discipline theory. Li Jinyun interprets the relation between language and subject in Travels in the Scriptorium based on Saussure's theory of semiotics and Lacan's subject theory.

Studies on Auster from cultural perspectives have been well received by scholars. Jia Jie, in her thesis "The City of Glass of Wanderers - An Analysis of City of Glass", interprets the wanders in City of Glass based on the image of Benjamin. In "City and Frontier: the American writing in Moon Palace", Ding Dong argues that New York and the west are not the pure physical space any more, they are the objects of American culture. In the paper "American Society in the Eyes of Mr. Bones - An Interpretation of Timbuktu by Paul Auster ", professor Xue Yufeng argues that Auster creates a mild, civilized and thoughtful dog, Mr. Bones in the novel, the author attempts to remind us that we should abandon the male centralism and anthropocentrism and criticize the disadvantages resulted from consumerism by $\mathrm{Mr}$. Bones' experience, and attempts to build harmonious relation between human beings and animals with ecological ethics consciousness. In the thesis "The Urban Writing in The New York Trilogy", Qi Shuo explores how the protagonists in The New York Trilogy construct their urban space based on the theories of De Certeau by analyzing the resistance of "caged beasts" and the walking of "caged beasts".

\section{CONCLUSION}

Paul Auster has adopted various writing strategies in his works, each of which has been praised for its compelling characters, razor-sharp prose, narrative complexity, and skillful use of point of view. However, despite the diversity of playing with literary techniques, the central themes and concerns of Paul Auster's fiction remain constant. Paul Auster's reappearing subjects are: coincidence, frequent portrayal of an ascetic life, a sense of imminent disaster, an obsessive writer as central character or narrator, loss of the ability to understand, loss of language, loss of money having a lot, but losing it little by little without earning some new money any more, depiction of daily and ordinary life, failure, absence of a father, writing and storytelling, search for identity and personal meaning, American history, American space, etc. At the core of all his writing is a deep moral concern, that is, what morality is, and how and why it can survive in a culture that would seen to deny its existence except as a marketing tool. Above all, Paul Auster studies should be further pushed from various perspectives.

\section{REFERENCES}

[1] Airriess, Christopher A. and Ines M. Miyares. Exploring Contemporary Ethnic Geographies. Contemporary Ethnic Geographies in America. ed. Ines M. Miyares. New York: Rowman \& Littlefield Publishers, 2006.

[2] Auster, Paul. City of Glass. New York: Penguin Books, 1990.

[3] Auster, Paul. Ghosts. New York: Penguin Books, 1990.

[4] Auster, Paul. Hand to Mouth: A Chronicle of Early Failure. London: Faber, 1997.

[5] Auster, Paul. In the Country of Last Things. New York: Faber and Faber, 2005.

[6] Auster, Paul. Invisible. New York: Henry Holt, 2009.

[7] Auster, Paul. Leviathan. New York: Penguin Books, 1993.

[8] Auster, Paul. Man in the Dark. New York: Henry Holt, 2008.

[9] Auster, Paul. Moonlight in the Brooklyn Museum. Art News. 86 (7) (1987): 105-106

[10] Auster, Paul. Moon Palace. New York: Penguin Books, 1990.

[11] Auster, Paul. Mr. Vertigo. New York: Penguin Books, 1995.

[12] Auster, Paul. Auster, Paul. Oracle Night. New York: Picador USA. 2009.

[13] Auster, Paul. The Art of Hunger: Essays, Prefaces, Interviews. New York: Penguin, 1993.

[14] Auster, Paul. The Book of Illusions. New York: Henry Holt, 2008.

[15] Auster, Paul. The Brooklyn Follies. New York: Henry Holt, 2006.

[16] Auster, Paul. The Invention of Solitude. New York: Penguin Books, 2007.

[17] Auster, Paul. The Locked Room. New York: Penguin Books, 1990.

[18] Auster, Paul. The Music of Chance. New York: Penguin Books, 1991.

[19] Auster, Paul. The New York Trilogy. New York: Penguin Books, 2006.

[20] Auster, Paul. The Red Notebook. Pennsylvania: University of Pennsylvania Press, 1995.

[21] Auster, Paul. Timbuktu. New York: Henry Holt, 1999.

[22] Auster, Paul. Travels in the Scriptorium. New York: Holtzbrinck Publishers, 2007.

[23] Auster, Paul. Sunset Park. New York: Henry Holt, 2010.

[24] Barone, Dennis. Beyond the Red Notebook: Essays on Paul Auster. Pennsylvania: University of Pennsylvania Press, 1995.

[25] Barnacle, Hugo. Invisible by Paul Auster. The Sunday Times. 25 (2009):64-73.

[26] Berlatsky, Eric. Everything in the World Has Its Own Color Detecting Race and Identity in Paul Auster's Ghosts. Arizona Quarterly, 64(3) (2008): 109-142.

[27] Bloom, Harold. Bloom's Modern Critical Views: Paul Auster. Philadelphia: Chelsea House Publishers, 2004.

[28] Brault, Pascale-Anne. Translating the Impossible Debt: Paul Auster's City of Glass. Critique: Studies in Contemporary Fiction 39(3) (1997) 228-238.

[29] Butler, M. and J.M.Gurr. The Poetics and Politics of Metafiction Reading Paul Auster's Travels in the Scriptorium. English Studies. 89(2) (2008):195-209. 
[30] González, Jesús Ángel. 'Another History': Alternative Americas in Paul Auster's Fiction. Comparative American Studies, March ( 2011): 21-34.

[31] Mallia, Joseph. Interview with Paul Auster. Conversations with Paul Auster. ed. James M. Hutchisson. Jackson: University Press of Mississippi, 2013.

[32] Martin, Brendan. Paul Auster's Postmodernity. New York: Routledge, 2010

[33] Morris, Mary. A Conversation with Paul Auster. Conversations with Paul Auster. ed. Hutchisson James M. Jackson: University Press of Mississippi, 2013.

[34] Obourn, Nick. Paul Auster on His New Novel, Invisible. Conversations with Paul Auster. ed. James M. Hutchisson. Jackson: University Press of Mississippi, 2013.

[35] Woods, T. The Music of Chance: Aleatorial (Dis)harmonies. Beyond the Red Notebook. ed. D. Barone. Philadelphia: University of Pennsylvania Press, 1995.

[36] Woods, T. Paul Auster: The Art of Fiction. Conversations with Paul Auster. ed. James M. Hutchisson. Jackson: University Press of Mississippi, 2013 